\title{
ANALISIS INDUSTRI PERBANKAN SYARIAH DI INDONESIA
}

\author{
Hasan \\ Fakultas Ekonomi Universitas Wahid Hasyim Semarang \\ E-mail: hasan_uwh@yahoo.com
}

Diterima 19 April 2011/Disetujui 13 Juni 2011

\begin{abstract}
Abtract: The current development of Islamic banking industry in Indonesia is rapidly growing. This article analyzes the Islamic banking industry in Indonesia using Porter's five-forces competitive industry approach. Each of the power industry are discussed. The conclusion indentifies Islamic banking industry conditions that need to be considered.
\end{abstract}

Keyword: islamic banking industry, Porter's five-forces competitive industry approach, power industry

Industri perbankan syariah telah mengalami perkembangan yang pesat. Dengan diterbitkannya UndangUndang No.21 Tahun 2008 tentang Perbankan Syariah pada tanggal 16 Juli 2008, pengembangan industri perbankan syariah nasional semakin memiliki landasan hukum yang memadai dan akan mendorong pertumbuhannya secara lebih cepat lagi. Perkembangan bank syariah cukup impresif, dengan rata-rata pertumbuhan aset lebih dari $65 \%$ pertahun dalam lima tahun terakhir, maka diharapkan peran industri perbankan syariah dalam mendukung perekonomian nasional akan semakin signifikan.

Pertumbuhan jaringan kantor perbankan syariah juga mengalami perkembangan yang pesat (lihat tabel 1). Pertumbuhan pesat ini terutama pada pert- ambahan jumlah kantor yang tumbuh lebih dari 100 \% selama 2005-2010 pada jumlah kantor bank umum syariah (BUS) dan bank pembiayaan rakyat syariah (BPRS). Pertumbuhan jumlah bank pun mengalami perkembangan yang pesat. Pada BUS pertumbuhan jumlahnya dari 3 menjadi 6 BUS , atau mencapai $100 \%$ dalam 5 tahun terakhir (2005-2010), Unit Usaha Syariah (UUS) pertumbuhannya mencapai 32\% (19 menjadi 25), dan BPRS mencapai 52\% (92 menjadi 140). Pertumbuhan yang tinggi ini membuktikan bahwa daya tarik perbankan syariah di Indonesia sangat tinggi. Pertumbuhan ini diperkirakan akan terus berlanjut karena aset perbankan syariah belum mencapai 5\% sebagaimana target yang ditetapkan Bank Indonesia (BI) pada akhir 2008 lalu.

Tabel 1. Jaringan Kantor Perbankan Syariah

\begin{tabular}{|l|r|r|r|r|r|r|r|r|r|r|r|r|r|}
\hline & 2005 & 2006 & 2007 & $\begin{array}{c}\text { Mar- } \\
08\end{array}$ & $\begin{array}{c}\text { Jun- } \\
08\end{array}$ & $\begin{array}{c}\text { Sep- } \\
08\end{array}$ & $\begin{array}{c}\text { Dec- } \\
08\end{array}$ & $\begin{array}{c}\text { Mar- } \\
09\end{array}$ & $\begin{array}{c}\text { Jun- } \\
09\end{array}$ & $\begin{array}{c}\text { Sep- } \\
09\end{array}$ & $\begin{array}{c}\text { Nov- } \\
09\end{array}$ & $\begin{array}{c}\text { Dec- } \\
09\end{array}$ & $\begin{array}{c}\text { Jan- } \\
10\end{array}$ \\
\hline $\begin{array}{l}\text { Bank Umum Syariah } \\
\text { - Jumlah Bank } \\
\text { - Jumlah Kantor } \\
\begin{array}{l}\text { Unit Usaha Syariah } \\
\text { - Jumlah Bank Umum Konvensional }\end{array}\end{array}$ \\
$\begin{array}{l}\text { yang memiliki UUS } \\
\text { - Jumlah Kantor }\end{array}$ & 304 & 349 & 401 & 402 & 405 & 497 & 581 & 635 & 643 & 660 & 701 & 711 & 815 \\
$\begin{array}{l}\text { Bank Pembiayaan Rakyat Syariah } \\
\text { - Jumlah Bank }\end{array}$ & 154 & 183 & 196 & 207 & 214 & 216 & 241 & 253 & 256 & 264 & 286 & 287 & 268 \\
- Jumlah Kantor & 92 & 105 & 114 & 117 & 124 & 128 & 131 & 133 & 133 & 137 & 138 & 138 \\
\hline Total Kantor & 92 & 105 & 185 & 188 & 195 & 199 & 202 & 208 & 208 & 220 & 224 & 225 & 263 \\
\hline
\end{tabular}

Sumber : Bank Indonesia, 2010 
Bank Indonesia telah menyusun kebijakan pengembangan perbankan syariah di Indonesia, dengan menerbitkan "Cetak Biru Pengembangan Perbankan Syariah di Indonesia" pada tahun 2002. Berbagai aspek telah dipertimbangkan secara komprehensif dalam penyusunannya, antara lain kondisi aktual industri perbankan syariah nasional beserta perangkat-perangkat terkait, trend perkembangan industri perbankan syariah di dunia internasional dan perkembangan sistem keuangan syariah nasional, kerangka sistem keuangan yang bersifat lebih makro seperti Arsitektur Perbankan Indonesia (API) dan Arsitektur Sistem Keuangan Indonesia (ASKI) maupun international best practices yang dirumuskan lembaga-lembaga keuangan syariah internasional, seperti IFSB (Islamic Financial Services Board), AAOIFI (Accounting and Auditing Organisation for Islamic Financial Institution) dan IIFM (International Islamic Financial Market). Sasaran yang ingin dicapai dalam kurun waktu 10 tahun adalah pencapaian pangsa pasar perbankan syariah yang signifikan melalui pendalaman peran perbankan syariah dalam aktivitas keuangan nasional, regional dan internasional, dalam kondisi mulai terbentuknya integrasi dengan sektor keuangan syariah lainnya. Dalam jangka pendek, perbankan syariah nasional lebih diarahkan pada pelayanan pasar domestik yang potensinya masih sangat besar. Dengan kata lain, perbankan Syariah nasional harus sanggup untuk menjadi pemain domestik akan tetapi memiliki kualitas layanan dan kinerja yang bertaraf internasional. Pada akhirnya, sistem perbankan syariah yang ingin diwujudkan oleh Bank Indonesia adalah perbankan syariah yang modern, yang bersifat universal, terbuka bagi seluruh masyarakat Indonesia tanpa terkecuali.

Bank Indonesia telah merumuskan sebuah Grand Strategi Pengembangan Pasar Perbankan Syariah, sebagai strategi komprehensif pengembangan pasar yang meliputi aspek-aspek strategis, yaitu: Penetapan visi 2010 sebagai industri perbankan syariah terkemuka di ASEAN, pembentukan citra baru perbankan syariah nasional yang bersifat inklusif dan universal, pemetaan pasar secara lebih akurat, pengembangan produk yang lebih beragam, peningkatan layanan, serta strategi komunikasi baru yang memposisikan perbankan syariah lebih dari sekedar bank.

Komitmen pemerintah Indonesia untuk mengembangkan perbankan syariah terlihat bagitu besar. Hal ini didorong oleh potensi pasar yang sangat besar sehingga membuat peningkatan drastis pemain dalam bank syariah. Apalagi penduduk Indonesia sebagian besar adalah muslim. Komitmen ini telah dibuktikan dengan disusunnya Undang-Undang Perbankan Syariah.

Didorong oleh perkembangan industri perbankan syariah yang sangat pesat di Indonesia, artikel ini disusun untuk menunjukkan persaingan dalam industri perbankan syariah dan situasi persaingan dalam industri keuangan, sehingga dapat memberi input informasi untuk penyusunan strategi bersaing perusahaan yang bermain dalam industri perbankan syariah.

\section{PEMBAHASAN}

Analisis industri perbankan syariah ini akan dilakukan dengan menganalisis struktur dan perubahan dalam struktur industri, mekanisme, persaingan dan pesaing, kesempatan dan ancaman, dan konteksnya: baik masa lalu, saat ini, maupun masa mendatang. Analisa ini akan menggunakan pendekatan yang umum digunakan pada analisis industri, yaitu analisa industri oleh Michael E. Porter.

Porter (1980) telah mengungkapkan lima kekuatan persaingan (Five Competitive Forces) yang menentukan kekuatan perusahaan dalam industri untuk mendapat keuntungan yang memadai. Lima kekuatan ini yang menentukan struktur industri dan intensitas persaingan. Lima kekuatan tersebut adalah (1) ancaman produk pengganti, (2) ancaman pesaing yang ada, (3) ancaman pendatang baru, (4) daya tawar pemasok, serta (5) daya tawar konsumen (lihat gambar 1). Pendekatan lima kekuatan ini pula yang akan digunakan dalam analisis industri perbankan syariah.

Gambar 1. Elemen-Elemen Struktur Industri oleh Porter (1980)

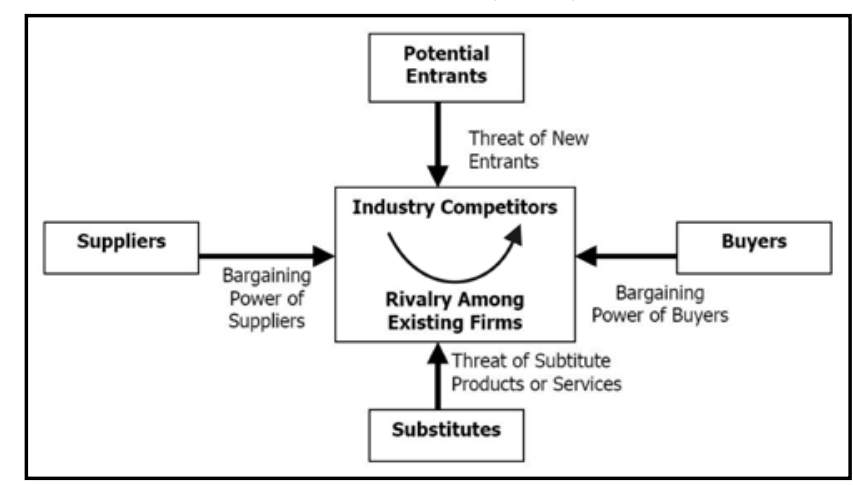




\section{Ancaman Pendatang Baru}

Pendatang baru dalam industri biasanya membawa kapasitas baru. Hal ini terutama jika dilakukan oleh pemain yang sudah pengalaman dalam dunia keuangan. Bank konvensional (non-syariah) dapat masuk ke dalam industri perbankan syariah baik dengan mendirikan bank umum baru, maupun dengan mendirikan unit usaha syariah (UUS). Hal ini memang difasilitasi dan dijelaskan secara jelas dalam UndangUndang No. 21 tahun 2008. Jelas sekali dari jumlah bank dan kantor cabang, peningkatan jumlah yang pesat lima tahun terakhir (lihat tabel 1). Hal ini diperkirakan akan terus berlanjut, mengingat aset bank syariah yang belum mencapai $5 \%$ dari aset perbankan nasiona, sedangkan potensi pasar bank syariah masih sangat terbuka luas. Hal ini pasti akan mendorong pemain lain untuk masuk ke dalam industri perbankan syariah. Pemain-pemain lain tersebut dapat bersumber dari : bank konvensional (dengan membuka UUS, atau mengakuisisi bank lain dan mengubahnya ke syariah), bank konvensional yang merubah operasionalnya menjadi syariah (spin-off), atau lembaga keuangan mikro lain, seperti Baitul Maal wat Tamwil (BMT) atau Koperasi Syariah yang membuka BPRS.

Arsitektur Perbankan Indonesia (API) mensyaratkan bahwa bank-bank yang tidak memenuhi persyaratan modal minimum, didorong untuk merger dengan bank lain, membatasi operasionalnya, atau mencari investor baru. Hal ini akan mendorong akuisisi bank-bank kecil untuk dirubah menjadi syariah sebagaimana telah terjadi pada Bank Syariah Mandiri dan Bank Rakyat Indonesia Syariah yang induknya (Bank Mandiri dan BRI) mengakuisisi bank kecil dan kemudian mengajukan perubahan menjadi bank umum syariah. Fenomena ini terjadi pula pada BPRS yang sebagian merupakan bank yang tidak memenuhi syarat lagi dan kemudian diambil alih oleh investor lain (kebanyakan lembaga keuangan mikro syariah) untuk dijadikan BPRS.

Sebagaimana disampaikan Porter (1980), untuk menghambat pemain baru masuk dapat digunakan hambatan masuk (entry barriers) berikut:

- Skala ekonomi; skala ekonomi adalah keunggulan biaya yang berhubungan dengan ukuran yang besar. Semakin besar skala usaha, maka diharapkan akan meningkatkan keunggulan biaya. Hal ini tampaknya tidak mudah dilakukan karena skala ekonomi bank syariah yang masih kecil. Hal ini akan sangat berisiko jika pemain-pemain besar bank umum terus masuk, khususnya dimulai dengan pembukaan UUS. Dalam perbankan dikenal istilah too-big-too-fail. Istilah ini digunakan untuk bank-bank yang sangat besar dan berpotensi sistemik jika bank tersebut ditutup, sehingga akan mendorong pemerintah menyelamatkan bankbank seperti ini jika mengalami kesulitan ${ }^{1}$. Bank yang dianggap besar ini lebih menarik bagi nasabah, karena mereka merasa aman dengan simpanannya daripada di bank kecil. Dengan relatif kecilnya bank-bank syariah saat ini, persaingan dengan bank-bank besar untuk mendapat nasabah menjadi tantangan tersendiri.

- Diferensiasi produk; identifikasi merek menciptakan penghalang masuk dengan memaksa pendatang untuk memberikan pengeluaran yang cukup besar untuk mengatasi loyalitas pelanggan yang sudah ada. Hal ini dapat dilakukan dengan menjaga loyalitas nasabah bank syariah yang sudah ada, dan melakukan inovasi-inovasi produk keuangan. Inovasi ini haruslah tetap sesuai dengan prinsip syariah, namun sekaligus mampu menjawab permintaan dan perkembangan produk keuangan konvensional yang begitu pesat. Karena itu, inovasi produk keuangan syariah yang lebih progresif mutlak dilakukan. Kelemahan perbankan syariah diantaranya adalah diferensiasi produk yang tidak sefleksibel perbankan konvensional karena dibatasi dengan aturan-aturan syariah, dan harus mendapat persetujuan Dewan Pengawas Syariah dan sesuai dengan rekomendasi Dewan Syariah Nasional. Disinilah peran Dewan Syariah Nasional diperlukan untuk melakukan penelitian dan pengembangan produk-produk keuangan syariah ke depan sehingga dapat memenuhi kebutuhan keuangan masyarakat tanpa bertentangan dengan ketentuan syariah.

- Kebutuhan modal; kebutuhan untuk menginvestasikan sumber daya keuangan dalam jumlah yang sangat besar akan menciptakan penghalang masuk yang signifikan. Kebutuhan modal dalam industri perbankan memang relatif besar, hal ini dapat menjadi penghambat masuknya pemain baru. Apalagi dengan target minimal modal bank yang harus dipenuhi oleh masing-masing bank. Namun kebutuhan modal minimal pendirian bank

1) Fenomena penyelamatan ini pernah terjadi di Indonesia dengan rekapitalisasi perbankan pada saat krisis moneter 1998 dan bail-out Bank Century yang saat ini menuai kontroversi. 
syariah yang relatif lebih kecil jika dibanding pendirian bank konvensional dapat mendorong para pemodal perbankan untuk masuk ke industri perbankan syariah ini. Hal ini harus diwaspadai oleh para pemain bank syariah saat ini.

- Biaya untuk berpindah (switching cost); switching cost adalah biaya yang dikeluarkan oleh pembeli ketika ia berpindah dari satu pemasok ke pemasok lain. Dalam industri perbankan, perpindahan nasabah peminjam dan penabung memang sangat mudah. Banyak bank yang memberikan fasilitas takeover simpanan / pinjaman dengan mudah. Namun persyaratan administratif dan biaya nonkeuangan, seperti loyalitas dan kepercayaan terhadap pelaksanaan prinsip syariah dapat menjadi nilai tambah tersendiri, minimal untuk tidak berpindah ke bank konvensional.

- Keunggulan biaya absolut; pada bank syariah yang sudah ada, memiliki keunggulan kurva pembelajaran yang lebih kuat daripada pemain baru, khususnya dalam pelaksanaan prinsip-prinsip syariah. Input SDM juga telah dimiliki terlebih dahulu, termasuk akses pendukung yang lain, seperti notaris dan jaringan yang telah dimiliki. Hal ini menjadi keunggulan bagi bank syariah yang telah ada.

- Akses ke saluran distribusi; pendatang baru mungkin membutuhkan penghalang masuk untuk mengamankan distribusi produknya. Distribusi terhadap nasabah bank umum syariah yang relatif besar biasanya dapat diintensifkan melalui lembaga keuangan mikro syariah (LKMS), baik Bank Pembiayaan Rakyat Syariah (BPRS), koperasi syariah, maupun Baitul Maal wat Tamwil (BMT). Program ini dikenal dengan Channelling, yang menjadi salah satu strategi distribusi pada dunia perbankan dan keuangan. Dalam rangka menjalankan strategi ini, akses terhadap LKMS yang sudah ada dan dimiliki oleh bank umum syariah saat ini perlu dibina dan dijaga.

- Kebijakan pemerintah; Penentu kebijakan perbankan adalah pemerintah yang operasionalnya dilakukan oleh Bank Indonesia. Selain itu juga harus diperhatikan kebijakan lembaga pemerintah terkait dengan perbankan, seperti Lembaga Penjamin Simpanan (LPS). Pemerintah jelas memiliki kebijakan pengembangan perbankan syariah yang kuat. Hal ini terbukti dengan keluarnya Undang-Undang Nomor 21 tahun 2008 tentang
Perbankan Syariah sebagai landasan hukum operasional perbankan syariah yang semakin kuat. Bank Indonesia pun telah membentuk Direktorat Perbankan Syariah dari sebelumya hanya pada tingkat biro perbankan syariah.

\section{Persaingan Diantara Bank Syariah yang Telah Ada}

Beberapa penentu persaingan perusahaan yang telah ada (dalam hal ini bank syariah) menurut Michael E. Porter (1980) adalah sebagai berikut:

- Jumlah pesaing; jumlah pemain pada bank syariah saat ini memang masih sedikit, namun ke depan jumlah pesaing diperkirakan akan terus meningkat dengan masuknya pendatang baru. Hal ini terlihat dari trend perkembangan yang telah ada, dan diperkuat dengan terbitnya UU perbankan syariah sebagai landasan hukum yang sangat dibutuhkan oleh kalangan usaha perbankan syariah.

- Tingkat pertumbuhan industri; pertumbuhan industri perbankan syariah sangat tinggi, data bank Indonesia (dalam Irfan, 2009) total aset industri perbankan syariah telah meningkat 27 kali lipat dari 1,79 trilyun pada 2000 , menjadi 49,6 trilyun pada akhir tahun 2008 dengan rata-rata laju pertumbuhan aset dalam 5 tahun terakhir sebesar $46,3 \%$ per tahun. Kedepan, dengan pertumbuhan industri yang ditargetkan lebih dari $30 \%$, akan meningkatkan intensitas persaingan.

- Karakteristik barang atau jasa; karakteristik jasa perbankan syariah memang unik dibandingkan bank konvensional, yaitu kesesuaian dengan syariah Islam. Meskipun keunikan ini menjadi keunggulan, kompensasi bagi nasabah penyimpan, dan biaya yang dikenakan pada nasabah yang dibiayai (peminjam) haruslah bersaing dengan bank konvensional. Jika tidak dilakukan, bank syariah dapat ditinggalkan oleh konsumen yang rasional, dimana konsumen jenis ini melakukan transaksi pada bank syariah dengan pertimbangan costbenefit yang didapat. Hal ini akan berbeda dengan pasar bank syariah yang kebanyakan masih emosional market, dimana nasabah bank syariah lebih terdorong melakukan transaksi karena pertimbangan emosional, seperti kesesuaian dengan syariah Islam karena memberikan ketenangan hati (Hasan, 2007).

- Jumlah biaya tetap; Biaya tetap yang ditanggung 
menentukan efisiensi bank syariah. Jika bank menanggung biaya tetap yang relatif tinggi, maka harus mengusahakan pendapatan yang tinggi melalui jumlah nasabah yang banyak, sehingga menekan biaya tetap per nasabah yang makin menurun. Bank syariah menghadapi biaya tetap yang tinggi diantaranya untuk investasi kebutuhan teknologi yang tinggi. Kecenderungan biaya tetap yang tinggi dalam perbankan akan mendorong persaingan harga rendah pada bank untuk mendapat jumlah nasabah yang maksimal (melalui efisiensi dari skala ekonomi). Hal ini akan berpengaruh terhadap intensitas persaingan yang semakin tinggi.

- Kapasitas; Kapasitas besar pada tiap bank syariah yang tidak termanfaatkan akan mendorong persaingan yang tinggi. Namun justru tampaknya kapasitas layanan bank syariah masih relatif rendah dibandingkan dengan bank konvensional. Hal ini sebagaimana diidentifikasi dalam beberapa penelitian yang mengindikasikan pelayanan bank syariah masih rendah, khususnya jika dibandingkan dengan bank konvensional (Hasan, 2007).

- Tingginya penghalang untuk keluar; bank konvensional dapat melakukan konversi menjadi bank syariah, namun bank syariah tidak dapat mengkonversi menjadi bank konvensional sebagaimana diamanatkan dalam Undang-undang Nomor 21 tahun 2008 tentang Perbankan Syariah. Hal ini menghalangi bank syariah keluar dari industri perbankan syariah, sedangkan di lain pihak, bank konvensional dapat melakukan konversi menjadi bank syariah, sehingga persaingan akan semakin ketat.

- Diversitas pesaing; keberagaman bank syariah relatif rendah. Hal ini terlihat dari kecenderungan wilayah pelayanan, harga, produk, dan fasilitas yang cenderung sama. Dengan ini, maka persaingan akan cenderung ketat. Untuk itu, inovasi perlu dilakukan masing-masing bank untuk melakukan diferensiasi, sehingga mengurangi persaingan yang dapat mengarah menjadi kurang sehat.

\section{Ancaman Produk atau Jasa Pengganti (Substitusi)}

Produk penganti muncul dalam bentuk berbeda, tetapi dapat memuaskan kebutuhan yang sama dari produk industri. Menurut Porter (1980), penggantian produk membatasi pendapatan potensial dari suatu industri karena akan menentukan batas atas pada hargaharga produk perusahaan dalam suatu industri. Dengan kata lain, batas atas pada harga-harga perusahaan dalam suatu industri berpengaruh terhadap laba.

Substitusi produk bank syariah dapat digolongkan menjadi dua :

1. Bank konvensional; bank konvensional dapat menjadi substitusi bagi nasabah bank syariah. Nasabah bank memiliki pilihan untuk menjadi nasabah pada bank syariah maupun konvensional. Kemudahan berpindah, khususnya pada nasabah yang cenderung rasional berpotensi untuk berpindah ke bank konvensional. Sedangkan nasabah yang emosional akan cenderung tetap menjadi nasabah pada bank syariah, meskipun dapat berpindah ke bank syariah lain yang lebih baik. Dengan kata lain, buyer prospensity pada nasabah rasional relatif tinggi dibandingkan dengan nasabah emostional. Padahal konsumen bidang perbankan cenderuang rasional daripada emosional pada aspek-aspek syariah. Dengan ini, keberadaan bank konvensional harus diperhatikan sebagai kekuatan substitusi bagi industri bank syariah.

2. Lembaga keuangan lainnya; Lembaga keuangan memiliki kegiatan yang sama dengan bank, yaitu menghimpun dana dari unit surplus yang disalurkan lagi kepada unit yang defisit. Lembaga keuangan selain bank, diantaranya adalah asuransi, pasar modal, koperasi simpan-pinjam, leasing, pegadaian, dan modal ventura. Semuanya berusaha untuk mendapatkan dana dan atau menyalurkan dananya untuk kepentingan bisnis. Sehingga lembaga keuangan non-bank ini menjadi substitusi bagi bank, termasuk bank syariah. Dengan makin canggihnya produk keuangan dan perkembangan perekonomian, maka perkembangan lembaga keuangan menjadi begitu cepat. Hal ini harus diwaspadai oleh perbankan syariah pula.

\section{Kekuatan Penawaran Pembeli (Nasabah)}

Pembeli jasa bank adalah nasabah, baik nasabah penyimpan maupun peminjam (pengambil kredit). Nasabah membeli jasa, dengan memberikan pendapatan pada bank, baik dari fee based (pendapatan dari biaya jasa yang didapat dari nasabah), maupun spread based (pendapatn selisih bunga pinjaman dengan bunga simpanan). Bank syariah tidak beroperasi 
dengan bunga, maka penggunaan istilah spread based menjadi kurang tepat, sehingga lebih sesuai penggunaan istilah operating based, dimana merupakan selisih pendapatan operasional dengan pendapatan yang dibagi kepada nasabah.

Pembeli mempengaruhi industri melalui kemampuan mereka untuk menekan turunnya harga, permintaan terhadap kualitas atau jasa yang lebih baik, dan memainkan peran untuk melawan satu pesaing dengan lainnya. Pembeli atau kelompok pembeli kuat jika beberapa kondisi berikut ini dipenuhi (Porter, 1980):

- Pembeli (baca: nasabah) membeli sebagian besar produk atau jasa penjual; Jika terdapat beberapa nasabah besar yang mendominasi pendapatan bank, maka nasabah-nasabah tersebut akan memiliki daya tawar yang besar. Biasanya nasabah-nasabah seperti ini adalah nasabah korporasi. Struktur simpanan perbankan di Indonesia memperlihatkan dominasi simpanan nasabah-nasabah besar pada total simpanan nasabah di Indonesia. Hal ini dapat dilihat pada tabel 2 berikut yang memperlihatkan distribusi simpanan dalam jumlah rekening dan nilai nominal simpanan pada Agustus 2010 dan September 2010 sebagai gambaran struktur simpanan di Indonesia. Terlihat bahwa 97\% lebih rekening bernilai kurang dari Rp100juta, namun nilai totalnya hanya sekitar $18 \%$ dari keseluruhan simpanan, sedangkan kurang dari 3\% rekening menguasai sekitar $82 \%$ total simpanan di Indonesia. Hal ini memperlihatkan bahwa simpanan di Indonesia dikendalikan oleh nasabah-nasabah besar. Sangat mungkin struktur simpanan pada bank syariah juga memperlihatkan gambaran yang sama. Dengan struktur ini, daya tawar nasabah-nasabah besar harus diperhatikan oleh bank, termasuk bank syariah.

- Pembeli memiliki kemampuan potensial untuk mengintegrasi ke belakang dengan memproduksi sendiri; dalam konteks bank syariah, relasi dan nasabah-nasabah besar akan dapat membuat sendiri bank syariah. BPRS yang meneriman program channelling dari bank umum syariah, seiring dengan besarnya mereka dapat meningkatkan banknya menjadi bank umum syariah; koperasi syariah atau BMT yang maju juga terdorong untuk dapat membuat BPRS sendiri. Dengan kemampuan keuangan yang dimiliki, memampukan mereka membuat bank syariah.

- Pemasok alternatif sangat dimungkinkan karena produknya standar atau tidak berbeda; dalam industri perbankan syariah, kecenderungan produkya adalah sama karena produk keuangan syariah harus sesuai dengan kebijakan Dewan Syariah Nasional (DSN) dan persetujuan dari Dewan Pengawas Syariah (DPS) atas dasar pedoman fatwa DSN. Hal ini akan meningkatkan intensitas persaingan diantara bank syariah. Untuk itu, inovasi menjadi produk dengan standar ini hendaknya dikembangkan sendiri oleh bank syariah.

Tabel 2. Distribusi Simpanan di Indonesia

\begin{tabular}{|c|c|c|c|c|c|c|}
\hline \multirow{10}{*}{$\begin{array}{l}\text { Rekening } \\
\text { (Ribu) }\end{array}$} & \multirow{2}{*}{$\begin{array}{l}\text { Jumlah Nominal } \\
(\mathrm{N})\end{array}$} & \multicolumn{2}{|c|}{ Agustus 2010} & \multicolumn{2}{|c|}{ September 2010} & \multirow{2}{*}{ Naik (Turun) } \\
\hline & & Rekening & $\%$ & Rekening & $\%$ & \\
\hline & $\mathrm{N} \leq 100 \mathrm{Jt}$ & $92.422,03$ & $97,76 \%$ & $93.428,73$ & $97,73 \%$ & $1.006,70$ \\
\hline & $100 \mathrm{Jt}<\mathrm{N} \leq 200 \mathrm{Jt}$ & 963,21 & $1,02 \%$ & 983,96 & $1,03 \%$ & 20,75 \\
\hline & $200 \mathrm{Jt}<\mathrm{N} \leq 500 \mathrm{Jt}$ & 667,34 & $0,71 \%$ & 679,94 & $0,71 \%$ & 12,60 \\
\hline & $500 \mathrm{Jt}<\mathrm{N} \leq 1 \mathrm{M}$ & 265,04 & $0,28 \%$ & 272,72 & $0,29 \%$ & 7,68 \\
\hline & $1 \mathrm{M}<\mathrm{N} \leq 2 \mathrm{M}$ & 123,92 & $0,13 \%$ & 128,96 & $0,13 \%$ & 5,04 \\
\hline & $2 \mathrm{M}<\mathrm{N} \leq 5 \mathrm{M}$ & 62,88 & $0,07 \%$ & 64,66 & $0,07 \%$ & 1,78 \\
\hline & $\mathrm{N}>5 \mathrm{M}$ & 34,81 & $0,04 \%$ & 36,09 & $0,04 \%$ & 1,28 \\
\hline & Total & $94.539,22$ & $100,00 \%$ & $95.595,06$ & $100,00 \%$ & $1.055,84$ \\
\hline \multirow{10}{*}{$\begin{array}{l}\text { Nominal } \\
\text { (Ribu) }\end{array}$} & Jumlah Nominal & \multicolumn{2}{|c|}{ Agustus 2010} & \multicolumn{2}{|c|}{ September 2010} & \multirow{2}{*}{ Naik (Turun) } \\
\hline & $(\mathrm{N})$ & Nominal & $\%$ & Nominal & $\%$ & \\
\hline & $\mathrm{N} \leq 100 \mathrm{Jt}$ & 386,09 & $18,27 \%$ & 386,09 & $17,79 \%$ & 0,00 \\
\hline & $100 \mathrm{Jt}<\mathrm{N} \leq 200 \mathrm{Jt}$ & 135,18 & $6,40 \%$ & 137,88 & $6,35 \%$ & 2,70 \\
\hline & $200 \mathrm{Jt}<\mathrm{N} \leq 500 \mathrm{Jt}$ & 215,47 & $10,19 \%$ & 218,89 & $10,09 \%$ & 3,42 \\
\hline & $500 \mathrm{Jt}<\mathrm{N} \leq 1 \mathrm{M}$ & 194,11 & $9,18 \%$ & 199,17 & $9,18 \%$ & 5,06 \\
\hline & $1 \mathrm{M}<\mathrm{N} \leq 2 \mathrm{M}$ & 173,85 & $8,22 \%$ & 179,08 & $8,25 \%$ & 5,23 \\
\hline & $2 \mathrm{M}<\mathrm{N} \leq 5 \mathrm{M}$ & 197,11 & $9,32 \%$ & 203,44 & $9,37 \%$ & 6,33 \\
\hline & $\mathrm{N}>5 \mathrm{M}$ & 811,97 & $38,41 \%$ & 845,86 & $38,97 \%$ & 33,88 \\
\hline & Total & $2.113,79$ & $100,00 \%$ & $2.170,41$ & $100,00 \%$ & 56,62 \\
\hline
\end{tabular}


- Biaya mengganti pemasok sangat rendah; perpindahan nasabah dari satu bank ke bank lain begitu mudah. Untuk itu, switching cost nasabah relatif rendah. Hal ini akan meningkatkan posisi tawar bagi nasabah, khususnya nasabah-nasabah besar.

- Produk yang dibeli mewakili persentase tinggi dari harga pokok pembeli, karena itu menyediakan insentif untuk harga yang lebih rendah; untuk nasabah-nasabah besar, pendapatan yang diminta oleh bank (pada pembiayaan ke nasabah) maupun harga simpanan nasabah (bagi hasil bank syariah kepada nasbah penyimpan) dapat dilakukan tawar-menawar untuk menekan harga produk keuangan bank syariah. Namun bagi nasabah penyimpan kecil (simpanan sampai dengan Rp. 2 milyar) yang dilindungi dengan penjaminan simpanan oleh Lembaga Penjamin Simpanan (LPS), namun dengan pembatasan bagi hasil untuk nasabah sesuai dengan ketentuan LPS.

- Pembeli mendapatkan laba yang rendah dan karena itu sangat sensitif untuk harga pokok dan jasa yang berbeda; dalam konteks nasabah bank, termasuk bank syariah, bagi hasil yang didapat relatif rendah dibandingkan pendapatan dari lembaga keuangan lain, seperti pasar modal maupun pegadaian. Dengan kemampuan mengakses pasar keuangan, mereka akan dapat menyeleksi lembaga keuangan mana yang akan memberikan keuntungan yang besar bagi mereka. Hal ini perlu diwaspadai bank syariah, khususnya pada saat persaingan bunga bank yang rendah pada bank konvensional akan dapat mempengaruhi nasabah pembiayaan bank syariah. Di lain pihak, pada saat bank konvensional meningkatkan bunga simpanan, bank syariah harus memberikan bagi hasil yang menarik pula agar tidak kehilangan nasabah penyimpan.

- Produk yang dibeli tidak penting untuk kualitas akhir atau harga dari produk atau jasa pembeli, dan dengan mudah diganti tanpa mempengaruhi kerugian pada produk akhir; produk jasa keuangan sangat penting bagi kegiatan ekonomi masyarakat. Dalam konteks bank syariah, permintaan terhadap produk ini cukup tinggi, mengingat jumlah masyarakat muslim yang cukup tinggi pula. Namun disisi lain, switching cost untuk ke produk keuangan lain juga rendah, sehingga meningkatkan bargaining power bagi nasabah.

Kedepan, dengan adanya program perlind- ungan dan pemberdayaan nasabah sebagaimana dicantumkan dalam program Arsitektur Perbankan Indonesia, nasabah akan cenderung makin kritis dan bank dituntut memberikan infomrasi yang transparan kepada pasar. Hal ini akan cenderung meningkatkan daya tawar nasabah. Pemberdayaan nasabah dalam konsep pengawasan perbankan sebagaimana Basel II menekankan pengawasan disiplin pengelolaan bank oleh pasar yang disebut dengan disiplin pasar. Adanya penekanan pada disiplin pasar akan semakin meningkatkan peran nasabah dalam melakukan pengendalian pengelolaan bank.

\section{Kekuatan Penawaran Pemasok}

Pemasok bank merupakan pemasok dana. Pemasok dana utama bank adalah nasabah penyimpan dan atau dari bank lain. Begitu pula dengan bank syariah yang mendapatkan dana dari masyarakat penyimpan dana, baik individu maupun organisasi/korporasi, kecil maupun besar.

Pemasok atau kelompok pemasok kuat jika beberapa persyaratan berikut ini dipenuhi (Porter 1980):

- Industri pemasok didominasi oleh sedikit perusahaan, tetapi menjual ke banyak perusahaan; pemasok dalam perbankan syariah tidak didominasi oleh sedikit nasabah atau bank, sehingga daya tawar pemasok relatif tidak kuat dibandingkan dengan industri lainnya. Namun yang perlu diperhatikan adalah struktur nasabah penyimpan, dimana jika nasabah penyimpan pada bank umum syariah sebagaimana gambaran umum pada perbankan nasional sebagaimana tabel 2 tadi, perlu diperhatikan dominasi nasabah penyimpan dengan nilai besar yang mendominasi simpanan.

- Produk atau jasanya unik dan atau produk itu mempunyai biaya pengganti yang menambah kekuatan; investor, lembaga keuangan lain dan nasabah penyimpan sebagai pemasok dana bank syariah relatif tidak memiliki perbedaan kebutuhan yang nyata dengan pemasok pada lembaga keuangan lain. Dalam dunia perbankan, keunikan pemasok relatif kecil karena para pemainnya banyak dan biaya untuk mengganti pemasok relatif kecil.

- Produk pengganti tidak tersedia; bank syariah sebagai bagian dari lembaga keuangan memiliki pemasok dana yang berbagai macam dan sal- 
ing menggantikan. Pemasok dana tidak terlalu kuat karena banyaknya alternatif pengganti dari satu sumber dana selama masih bersaing dengan produk keuangan bank lain.

- Industri pembeli membeli hanya sebagian kecil barang atau jasa dari kelompok pemasok dan itu tidak penting bagi pemasok; Aset perbankan syariah masih sangat kecil (kurang dari 5\% aset perbankan nasional), sehingga daya tawar perbankan syariah masih relatif kecil. Meskipun demikian, keberadaan perbankan syariah semakin penting dengan prospek masa depannya yang cerah dan dukungan pemerintah untuk mengembangkan perbankan syariah ini.

\section{KESIMPULAN}

Dari pembahasan di atas, dapat ditarik beberapa kesimpulan sebagai berikut :

1. Industri perbankan syariah berkembang dengan pesat namun relatif masih kecil dibandingkan dengan perbankan nasional dan industri keuangan secara umum. Perkembangan ini mendapat momentumnya dengan dikeluarkannya Undang-

\section{DAFTAR PUSTAKA}

Bank Indonesia. 2009. Laporan Pengawasan Perbankan 2008. Direktorat Penelitian dan Pengaturan Perbankan Bank Indonesia. Jakarta.

Bank Indonesia. 2010. Statistik Perbankan Syariah Januari 2010. Direktorat Perbankan Syariah Bank Indonesia. Jakarta

Hasan. 2007. "Pengaruh Kualitas Jasa Bank Syariah terhadap Kepuasan Nasabah". Jurnal Akses Fakultas Ekonomi Universitas Wahid Hasyim. Vol.1 No.1
Undang Nomor 21 tahun 2008 tentang perbankan syariah dan kebijakan pemerintah.

2. Ancaman pendatang baru begitu besar dengan tingginya pertumbuhan industri perbankan syariah nasional.

3. Persaingan dengan bank syariah yang ada saat ini relatif rendah, namun kedepan akan cenderung tinggi dengan banyaknya pendatang baru di bank syariah. Apalagi, bank syariah tidak dimungkinkan mengkonversi menjadi bank konvensional, sebaliknya, bank konvensional sangat dibuka kesempatannya untuk menjadi bank syariah.

4. Ancaman produk substitusi cenderung tinggi, yaitu produk keuangan dari bank konvensional maupun lembaga keuangan lain.

5. Kekuatan nasabah kecil cenderung lemah, sedangkan nasabah besar cenderung kuat. Kecenderungan ke depan, daya tawar nasabah akan semakin kuat.

6. Ancaman pemasok dana besar perlu diperhatikan karena daya tawar yang tinggi terhadap bank dan kecenderungan dibutuhkannya modal dan dana yang besar untuk memperkuat bank syariah.

Irfan S, Muhammad. 2009. Kebijakan Pengembangan Perbankan Syariah Indonesia. Makalah dalam Seminar Nasional Ekonomi Islam di Semarang, 5 Nopember 2009.

Porter, Michael E. 1980. Competitive Strategy :Techniqus for Analyzing Industries and Competitors. New York. Free Press 